Zuzanna Morawska-Zakroczymska*" Daria Gęsicka**:

\title{
CASE NOTE TO THE JUDGMENT \\ OF THE COURT OF JUSTICE OF 3 OCTOBER 2019 IN THE CASE EVA GLAWISCHNIG-PIESCZEK V. FACEBOOK IRELAND, C-18/18;
}

\begin{abstract}
The judgment of the Court of Justice of 3 October 2019 in case Eva Glawischnig-Piesczek v. Facebook Ireland, C-18/18, is one of the Court's multiple decisions concerning the liability of host providers and the obligations that may be imposed on them by a national court ${ }^{1}$. The decision seems to follow two current pan-European (or even global) trends as far as host providers' liability is concerned. The first is to make the liability rules stricter. The second is a shift from the concept of horizontal to that of vertical liability

* M.A. (law), LLM, junior associate at Bird and Bird Szepietowski i wspólnicy sp.k, e-mail: morawska.zuzanna@gmail.com.

** PhD, assistant professor at the Faculty of Law and Administration of the Nicolaus Copernicus University in Torun, Of Counsel at Bird and Bird Szepietowski i wspólnicy sp.k., e-mail: dgesicka@umk.pl.

*** Eva Glawischnig-Piesczek v. Facebook Ireland Limited, case C-18/18, Judgment of 3.10.2019, EU:C:2019:821, available at: http:/ / curia.europa.eu/juris/document/document. jsf?docid=218621\&doclang=EN [last accessed: 20.10.2019].

${ }^{1}$ See e.g. Scarlet Extended SA v. Société belge des auteurs, compositeurs et editeurs SCRL (SABAM), case C-70/10, Judgment of 24.11.2011, EU:C:2017:771 and Belgische Vereniging van Auteurs Componisten en Uitgevers CVBA (SABAM) v. Netlog NV, case C-360/10, Judgment of 16.02.2012, ECLI:EU:C:2012:85, available: http:/ / curia.europa.eu/juris/ liste.jsf?num=C-360/10\&language=EN [last accessed: 20.10 .2019$]$.
\end{abstract}


rules $^{2}$. In essence, the Court of Justice decided that a host provider might be ordered by a national court to remove (or block access to) defamatory content identical or equivalent to the information which had been previously declared unlawful. What is more, according to the Court a host provider may be ordered to remove (or block access) to such information worldwide as long as measures adopted by a member state allow its national courts to issue a worldwide order and the measures are consistent with applicable international law.

The judgment commented on will have a great impact on the content of claims lodged by plaintiffs in personal rights infringement cases, in particular in electronic communication. The efficacy of the court order in question, however, will depend on the imagination of plaintiffs (in how to formulate their claims so that a court order covers equivalent comments as well) and defendants (in how to express their opinions in such a way that the opinions are not covered by a court order). It will be also greatly affected by national courts whose job will be to interpret the notion of "equivalent information" and to find a balance between three groups of interests: plaintiffs, defendants, and a third party that may be affected by the order (e.g. users of an online platform).

\section{Keywords}

personal rights - online infringement - preventive injunction - equivalent content

\section{FACTS OF THE CASE}

The plaintiff, Eva Glawischnig-Piesczek, is an Austrian politician. She was a member of the Nationalrat (National Council), chair of the parliamentary party "die Grünen" (The Greens) and federal spokesperson for that party. The defendant, Facebook Ireland, operates a global social media platform ("Facebook Services") for users located outside the United States of America and Canada.

On 3 April 2016, a Facebook Services user shared on their personal page an article from the Austrian online news magazine oe24.at. That user also posted a harmful, insulting and defamatory (as decided by the

2 See in particular G. F. Frosio, From horizontal to vertical: an intermediary liability earthquake in Europe, Oxford Journal of Intellectual Property and Practice 12/2017, p. 1-18. Available at SSRN: https://ssrn.com/abstract=2956859 or http://dx.doi.org/10.2139/ ssrn.2956859 
referring court) comment. The post could be accessed by any Facebook user. In a letter, Ms Glawischnig-Piesczek asked Facebook Ireland to delete that comment.

Facebook Ireland did not block access to the comment in question. In consequence, Ms Glawischnig-Piesczek brought an action before the Handelsgericht Wien (Commercial Court, Vienna). By an interim injunction, the court ordered Facebook Ireland to immediately cease and desist from disseminating photographs of the plaintiff with the accompanying text if it contained the assertions, verbatim and/or used words having an equivalent meaning as that of the defamatory comment.

In effort to comply with the injunction, Facebook Ireland disabled access to the content initially published, with effect in Austria.

On appeal, the Oberlandesgericht Wien (Higher Regional Court in Vienna) upheld the order as regards the identical allegations. However, it also held that the dissemination of the equivalent allegations had to cease only as regards those brought to the knowledge of Facebook Ireland.

Each of the parties in the main proceedings lodged appeals on a point of law at the Oberster Gerichtshof (Austrian Supreme Court).

The Oberster Gerichtshof stated that, in accordance with its own case-law, such an obligation must be considered to be proportionate where the host provider was already aware that the interests of the person concerned had been harmed on at least one occasion as a result of a user's post and the risk that other infringements may be committed was thus demonstrated. The dispute, however, raised questions on the interpretation of the EU law, thus the court decided to stay down the proceedings and refer three questions to the Court of Justice.

\section{QUESTIONS}

The following questions were referred to the Court of Justice for a preliminary ruling:

“1. Does Article 15(1) of Directive [2000/31] generally preclude any of the obligations listed below of a host provider which has not expeditiously removed illegal information, specifically not just this illegal information within the meaning of Article 14(1)(a) of [that] directive, but also other identically worded items of information: 
- worldwide;

- $\quad$ in the relevant Member State;

- of the relevant user worldwide;

- of the relevant user in the relevant Member State?

2. In so far as Question 1 is answered in the negative: does this also apply in each case to information with an equivalent meaning?

3. Does this also apply to information with an equivalent meaning as soon as the operator has become aware of this circumstance?".

\section{JUDGMENT}

The Court of Justice reformulated the above questions and answered that Directive 2000/31, in particular Article 15 (1), must be interpreted as meaning that it does not preclude a court of a Member State from:

- ordering a host provider to remove information which it stores, the content of which is identical to the content of information which was previously declared to be unlawful, or to block access to that information, irrespective of who requested the storage of that information;

- ordering a host provider to remove information which it stores, the content of which is equivalent to the content of information which was previously declared to be unlawful, or to block access to that information, provided that the monitoring of and search for the information concerned by such an injunction are limited to information conveying a message the content of which remains essentially unchanged compared with the content which gave rise to the finding of illegality and containing the elements specified in the injunction, and provided that the differences in the wording of that equivalent content, compared with the wording characterizing the information which was previously declared to be illegal, are not such as to require the host provider to carry out an independent assessment of that content, and

- ordering a host provider to remove information covered by the injunction or to block access to that information worldwide within the framework of the relevant international law. 


\section{ANALYSIS OF THE JUDGMENT}

The main focus of the judgment is on the content of a court order and its territorial scope.

As insightfully noticed by Advocate General Szpunar in his opinion delivered on 4 June 20193, "the key issue in the present case is whether a host which operates an online social network platform may be required to delete, with the help of a metaphorical ink eraser, certain content placed online by users of that platform". To be more precise, the key element of the case was the proportionality of such an order in terms of its material and territorial scope. In particular, whether the host may be required to delete not only the content identical to infringing comments, but also the equivalent ones, and whether such erasure should be effective in the relevant Member State only or worldwide.

In the light of the above decision, there are three major issues which require further analysis. These are the following: the temporal and territorial scope of the injunctions as well as the notion of the equivalent content.

\section{TERRITORIAL SCOPE}

The concept of extraterritorial injunctions is not new to EU law. In the field of intellectual property law, the accessibility of pan-European injunctions has been confirmed by the CoJ numerous times, ${ }^{4}$, however mostly in relation to unitary rights (such as rights to European Union trademarks or community designs). At times, however, owing to the proportionality

${ }^{3}$ Eva Glawischnig-Piesczek v. Facebook Ireland Limited, case C-18/18, Opinion of Advocate General Szpunar delivered on 4.06.2019, EU:C:2019:458, available at: http:/ / curia.europa.eu/juris/document/document.jsf?docid=214686\&doclang=EN [last accessed: 20.10.2019].

${ }^{4}$ E.g. Nintendo Co. Ltd v. BigBen Interactive $\mathrm{GmbH}$ and BigBen Interactive SA, joined cases C-24/16 and C-25/16, Judgment of 27.09.2017, EU:C:2017:724, available at: http:/ / curia.europa.eu/juris/document/ document.jsf;jsessionid=83E5B065407F5ABBCD17987 4AC825307?text $=\&$ docid $=195045 \&$ pageIndex $=0 \&$ doclang $=E N \&$ mode $=1$ st $\&$ dir $=\& o c c=f i$ rst\&part=1\&cid=8645367 [last accessed: 20.10 .2019$]$. 
requirement, the $\mathrm{CoJ}$ decided that it was justified to limit the territorial scope of the injunctions. For an instance, in the CoJ's decisions in DHL Express France case (C-235/09) 5 and combit Software GmbH v. Commit Business Solutions Ltd. (C-223/15) ${ }^{6}$, both of which concerned the EU trademarks, the $\mathrm{CoJ}$ confirmed that, in general, injunctions should cover the entire territory of the EU since that reflects the territorial scope of their protection. In this way, the CoJ explained, it would be possible to guarantee unitary protection of the rights in the EU which is compliant with the aim of the regulation ${ }^{7}$. However, the CoJ also said that where there was no real risk of confusion (owing to linguistic aspects), the territorial scope of an injunction should be limited to only those Member States where the risk could be found.

Moreover, in Solvay SA v. Honeywell Companies (C-616/10) the CoJ extended the above rule, by means of interpreting Article 22(4) and Article 31 of Regulation No 44/2001 ${ }^{9}$, to European patents. Despite the territorial nature of European patents ${ }^{10}$ and their protection, the CoJ allowed for a cross-border prohibition against patent infringement to be

${ }^{5}$ DHL Express France SAS (formerly DHL International SA) v. Chronopost SA, case C-235/09, Judgment of 12.04.2011, EU:C:2011:238, available at: http:/ /curia.europa.eu/ juris $/$ document $/$ document.jsf?text $=\&$ docid $=81436 \&$ pageIndex $=0 \&$ doclang $=E N \&$ mode $=$ lst\&dir=\&occ $=$ first \&part $=1 \&$ cid $=8649828$ [last accessed: 20.10 .2019$]$.

${ }^{6}$ combit Software GmbH v. Commit Business Solutions Ltd, C-223/15, Judgment of 22.09.2016, EU:C:2016:719, available at: http://curia.europa.eu/juris/document/ document.jsf;jsessionid=9A6EA50FCBA84D6AB4F8A0DA939E93F8?text=\&docid=1837 $01 \&$ pageIndex $=0 \&$ doclang $=\mathrm{EN} \&$ mode $=1$ st $\&$ dir $=\& o c c=$ first $\&$ part $=1 \& \mathrm{cid}=9266390$ [last accessed: 20.10.2019].

7 Regulation (EU) 2017/1001 of the European Parliament and of the Council of 14 June 2017 on the European Union trade mark (Text with EEA relevance), Official Journal L 154 of 16 June 2017, p. 1-99.

${ }^{8}$ Judgment of the Court of Justice of 12 July 2012 in case C-616/10, Solvay SA v. Honeywell Fluorine Products Europe BV, Honeywell Belgium NV, Honeywell Europe NV, EU:C:2012:445, available at: http:/ / curia.europa.eu/juris/document/document.jsf?text= \&docid=124996\&pageIndex=0\&doclang=EN\&mode=lst\&dir=\&occ=first \&part=1\& cid=8650607 [last accessed: 20.10.2019].

${ }^{9}$ Council Regulation (EC) No 44/2001 of 22 December 2000 on jurisdiction and the recognition and enforcement of judgments in civil and commercial matters, OJ EU L 012, p. 1-23.

${ }^{10}$ See rec. 26 of the case C-616/10. 
issued by a national court since in the CoJ's opinion there was no risk of conflicting decisions being issued by different national courts.

However, since there is no pan-EU regulation on personal rights and their protection, the area is subject to national regulation. In other words, as wisely noted by the CoJ, the national rules of civil law and civil procedure of a particular Member State apply in case of personal rights and protective measures. In consequence, if the law of a Member State allows for a protective measure to have extraterritorial scope, no provision of the Directive 2000/31/ EC ${ }^{11}$ precludes a court of a Member State from ordering a host provider to remove information covered by the injunction in multiple jurisdictions (even globally). Yet, it has to be observed that the efficacy of such an order depends greatly on the framework of the relevant international law, in particular the rules of recognition and enforcement of decisions or judgments of a foreign court (international civil procedure). The procedure consists in, inter alia, verification of whether the order in question is not contrary to the basic rules of the public order of the Members State (public order clause) ${ }^{12}$. In cases concerning content blocking or removing orders, national courts of Member States should check an order issued by a foreign court against, inter alia, their national standard of freedom of speech, freedom of expression, and freedom of business operations.

\section{EQUUIVALENT CONTENT}

In this judgment, the CoJ dealt extensively with the limit of the national courts' powers to impose obligations on host providers in regard to blocking and removing illegal content.

Firstly, the CoJ ruled that the national court may order the host provider to block or remove information stored, the content of which is

11 Directive 2000/31/EC of the European Parliament and of the Council of 8 June 2000 on certain legal aspects of information society services, in particular electronic commerce, in the Internal Market ('Directive on electronic commerce'), Official Journal L 178 of 17 July 2000, p. 1-16, referred to as "Directive 2000/31/WE".

12 See e.g. Article 1146 of Polish act of 17 November 1964 Code of Civil Procedure, OJ 2019 item 1460 with amendments. 
identical to the content previously declared to be illegal irrespective of who requested the storage of that information. In other words, the CoJ stated that such injunction is permissible and falls under the specific case of monitoring allowed under recital 47 of Directive 2000/31.

Secondly, the CoJ stated that Directive 2000/31 does not prohibit granting orders for an injunction of information with an equivalent content to the messages declared illegal. It explained that the illegality of the information stems from the content conveyed by the terms and not the use of certain terms in certain way. Therefore, the injunction must be able to reach the information worded slightly differently, but essentially conveying the same message.

At this point, the judgment differs substantially from the AG's opinion. In recital 67 of the opinion, AG defined the equivalent information as information that scarcely diverges from the original information or information of which the message remains essentially unaltered. AG provided examples of reproduction of the information containing a typographical error and a reproduction having slightly altered syntax or punctuation as being 'equivalent information' to the one previously declared illegal. In recitals 72-73 of the opinion, AG restricted the host provider's obligation to block or remove such information to only those occasions when they are issued by the same user who disseminated the initial illegal information.

The AG narrowed down the meaning of information with an equivalent content and the monitoring obligations of host providers to an initial "offender". On the other hand, the CoJ sailed in uncharted waters by stating that the injunction may also concern information worded "slightly differently" but essentially conveying the same message. It leaves national courts with the difficult task of making decisions on the future illegality of an equivalent content - information that will be blocked for an indefinite period of time sometimes before it is actually posted.

The CoJ stated that a host provider may be ordered to carry out monitoring or search for the infringing equivalent content and at the same time, should not be ordered to make "an independent assessment" of the legal or illegal character of that content. It listed three elements that should be part of the injunction: 1) the name of the person concerned by the infringement, 2) the circumstances in which that infringement was determined, and 3) the differences in wording. 
However, the abovementioned criteria are to an extent contradictory because the host provider will only learn whether he needs to carry out that assessment after carrying out the monitoring, which cannot be then undone.

Moreover, the elements mentioned in the injunction may include subtle changes and require further analysis and actual "understanding" of the content's context. What if the messages are conveyed by way of satirical use or are represented in a meme or other audiovisual form? The host provider will need to balance between the freedom of speech and expression of its users and the injunction. However, according to the judgment the host provider cannot be obliged to carry out an independent assessment, so he may end up being caught between a rock and a hard place.

Another interesting aspect is the question of translations. FS allows automatic translation of the posts, so potentially this functionality could be used to circumvent the initial removal of content. Should then the FS translation be automatically recognized as equivalent content? If the national courts go in this direction, it could lead to the Europeanisation of personality rights infringements.

It can be noted that a claim for removal of a similar content to the infringing one is not a new concept. Similar injunctions or orders are formulated in IPRs infringement cases so that it is not possible for an infringer to circumvent a court order easily by introducing minor changes to their product. However, unlike the situation in cases of personal rights infringement, there are specific legal grounds that justify the issuance of such broad injunctions or orders. For example, under Article 9(2) of Regulation No 2017/1001 the proprietor of an EU trademark is entitled to prevent all unauthorized third parties from using, in the course of trade, in general, any sign identical or similar to their sign (on condition that other requirements indicated in the provision are met).

\section{TEMPORAL SCOPE}

Besides the above considerations, yet another significant issue, the temporal scope of the injunctions, requires comment. Although this was not the subject of any of the questions referred to the CoJ, owing to 
the proportionality requirement applicable to every protective measure, there is a need to ponder this aspect for a moment.

First, as far as the role of an injunction is concerned, pursuant to Article 14 (3) of the Directive 2000/31 the measure is not limited to the already existent infringements, but might be aimed at preventing future infringements by the same, or equivalent, content. This statement (with regard to preventive function) has never been a subject to controversy. An adverse interpretation of the provision would be contrary to its wording.

Second, the CoJ did not mention the period of time for which such an injunction is enforceable. It should be noted that in cases of personal rights infringements public interest shifts quite quickly from one person or event to another. Usually, the severity of personal rights infringement is stronger at its initial stage when the corresponding public interest in the matter is the most intense. With time, the public loses interest, there are fewer re-posts and comments, and the comments become more wellbalanced. Also, the status of the person concerned may change (e.g. she/ he might become a public official). Such changes might result in an injunction becoming disproportionate and having a chilling effect on freedom of speech and expression. In the light of the fact that an injunction can cover future identical of equivalent infringements, enforceability of an injunction should always be limited in time.

\section{PRACTICAL IMPLICATIONS OF THE JUDGMENT}

Following the CoJ's reasoning, an order issued by a national court may cover not only identical comments, but also equivalent ones. In the CoJ's opinion, for the order to be proportionate, it is the national court's duty: first, to determine that the basic information covered by the plaintiff's claim is illegal, second - to determine which words or phrases should be considered equivalent, and third - to determine in which circumstances the use of the equivalent content might amount to an infringement.

In practice, the burden of defining which information is the equivalent of the content previously declared to be unlawful will be shifted onto a plaintiff. Although, on the surface the judgment seems to be plaintifforiented, as far as its enforcement is concerned, it raises more questions than answers. The main dilemma for plaintiffs and their representatives 
then would be to formulate claims in a well-balanced manner. If a claim is too broad, a court might dismiss the claim, at least partially. This will, among other effects, determine which of the parties bears the costs of the proceedings. Where the claim is too narrow, its efficacy will be low.

It can be observed that the evolution of combating personal rights infringements on the Internet is already happening. In one of the recent Polish judgments, the court prohibited the use of a vulgar English word, even though it had many alternative meanings in Polish and the court itself stated that it is impossible to define the infringer's intended meaning ${ }^{13}$. However, in the Polish context, it is important to note that to obtain a preventive injunction, the plaintiff will also need to show a highly probable belief that an objectively justified violation of personal rights in the future is likely to occur ${ }^{14}$.

And last, but not least, the way in which the CoJ defined the notion of equivalent content and the scope of obligations that can be imposed on a host provider, raises the question of whether the CoJ introduced an obligation to use a (preventive) automated general filtering system via the back door. It may be the case as the monitoring of and search for information is to be limited to specific equivalent information (as specified in the injunction), but, at the same time, it may cover the content of any user, not only the one who committed the infringement already assessed by the court. In addition, the $\mathrm{CoJ}$ specified that monitoring obligation may not be such as to require the host provider to carry out an independent assessment of the content. Simultaneously it defined the elements of the injunction vaguely and did not specify how they should be "transferable" into the monitoring mechanism of equivalent content. It is rather clear that indentifying them in the particular case will require carrying out an assessment. Then the question left is what the risk is, which the host provider is facing, when blocking or removing after carrying out an "independent assessment" and what is the risk of not doing it. Even

${ }^{13}$ See Judgment of the Appeal Court in Cracow of 24.02.2016, case I ACa 1630/15, available at: http:/ / orzeczenia.ms.gov.pl/details/\$N/152000000000503_I_ACa_001630 _2015_Uz_2016-02-24_001 (in Polish only) [last accessed: 20.10.2019].

${ }^{14}$ See Judgment of the Appeal Court in Cracow of 4.11.2015, case I ACa 979/15, available at: http:/ / orzeczenia.ms.gov.pl/details/\$N/152000000000503_I_ACa_000979_2015_ Uz_2015-11-04_001 (in Polish only) [last accessed: 20.10.2019]. 
though the fact of acting in performance of a court order shields a host provider from contractual or tort liability, a tendency to remove allegedly illicit content might discourage users and affect the exercise of freedom of speech in a negative manner. Also, the obligation to implement and use automated general filtering system generates additional costs on the part of the host provider. This might be particularly detrimental to small and medium entrepreneurs. 